University of Nebraska - Lincoln

DigitalCommons@University of Nebraska - Lincoln

3-1-1994

\title{
Reaction Kinetics Analyses of Amine-Cured Epoxies: First Shell Substitution Effects
}

Hossein Noureddini

Department of Chemical Engineering, University of Nebraska-Lincoln, hnouredd@unlnotes.unl.edu

C Q. Zhang

Department of Chemical Engineering, University of Nebraska-Lincoln

Delmar C. Timm

University of Nebraska-Lincoln, dtimm1@unl.edu

Follow this and additional works at: https://digitalcommons.unl.edu/chemengreaction

Part of the Chemical Engineering Commons

Noureddini, Hossein; Zhang, C Q.; and Timm, Delmar C., "Reaction Kinetics Analyses of Amine-Cured Epoxies: First Shell Substitution Effects" (1994). Papers in Reaction Kinetics. 1.

https://digitalcommons.unl.edu/chemengreaction/1

This Article is brought to you for free and open access by the Chemical and Biomolecular Engineering Research and Publications at DigitalCommons@University of Nebraska - Lincoln. It has been accepted for inclusion in Papers in Reaction Kinetics by an authorized administrator of DigitalCommons@University of Nebraska - Lincoln. 
H. Noureddini, C.-Q. Zhang, and D. C. Timm, Reaction Kinetics Analyses of Amine-Cured Epoxies: First Shell Substitution Effects. C Macromolecules; 1994; 27(8); 2045-2053.

Reaction Kinetics Analyses of Amine-Cured Epoxies: First Shell Substitution Effects

\author{
H. Noureddini, C.-Q. Zhang , and D. C. Timm \\ Received September 2, 1993; Revised Manuscript Received January 7, 1994 \\ (C) Macromolecules; 1994; 27(8); 2045-2053.
}

Abstract published in Advance ACS Abstracts, March 1,1994 .

Copyright (C) 1994 American Chemical Society.

The American Chemical Society allows posting only title, abstract, tables, and figures from articles appearing in the Macromolecules.

Published version of this article is available at the publishers site:

http://pubs.acs.org/cgi-bin/archive.cgi/mamobx/1994/27/i08/pdf/ma00086a011.pdf

\begin{abstract}
:
Kinetic reaction theory was used to model first shell substitution effects for several aminecured epoxy resins, subject to the constraint of intermolecular reactions. Moment analysis will allow numerical simulations to be extended beyond the gel point. Functionalities for several chemical moieties were correlated as a function of conversion. Simulations also incorporated population density distribution dynamics. Analyses of several oligomers clearly demonstrated the dependency of oligomeric weight fractions on first shell substitution effects and conversion. The ratio of rate constants for reactions of secondary amino hydrogens relative to reactions of primary amino hydrogens ranged from 0.5 to 1.2 for the resins analyzed.
\end{abstract}


H. Noureddini, C.-Q. Zhang, and D. C. Timm, Reaction Kinetics Analyses of Amine-Cured Epoxies: First Shell Substitution Effects. (C) Macromolecules; 1994; 27(8); 2045-2053.
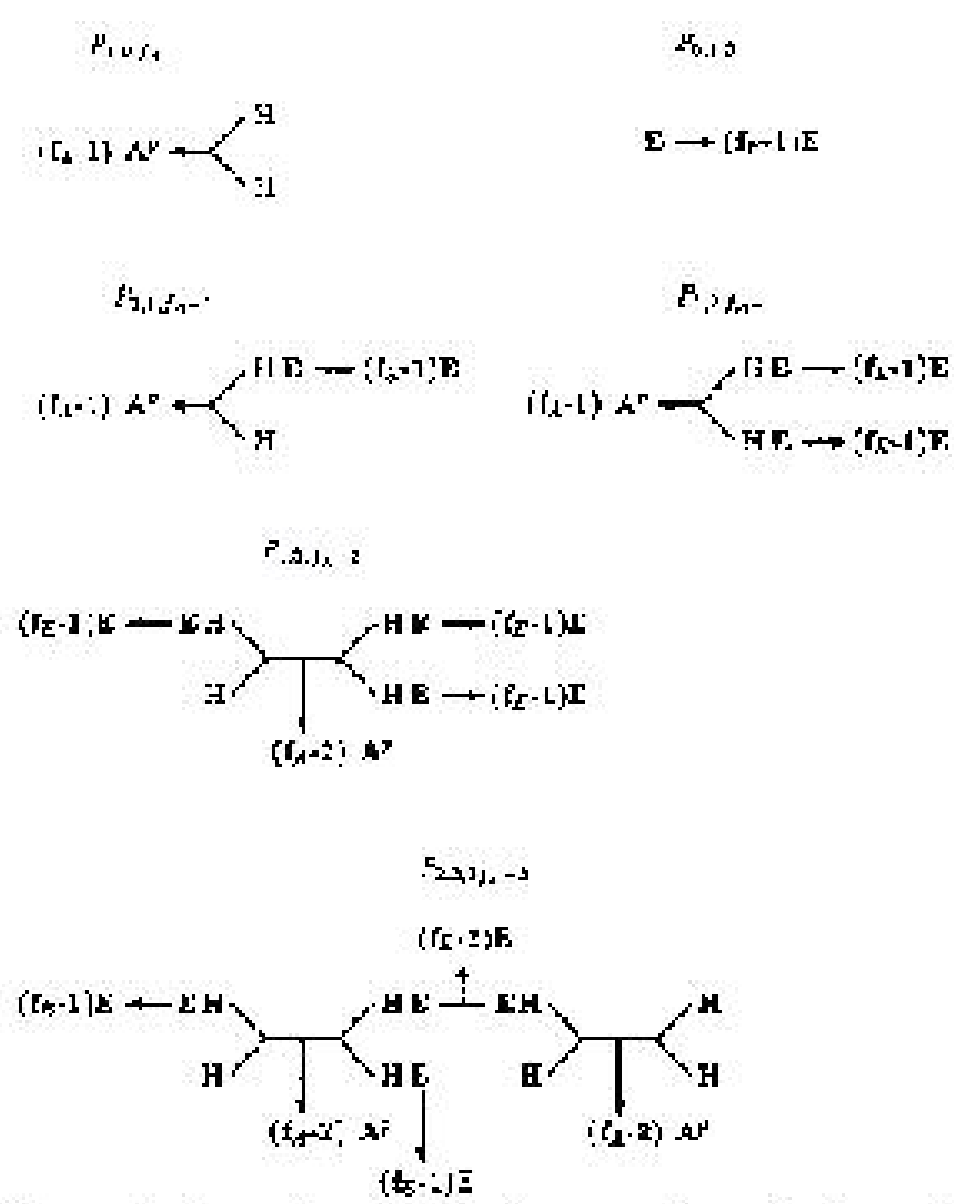

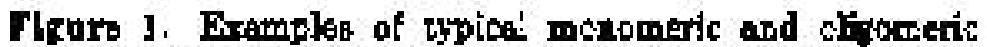
molecnles reaulting trom the resction of prityegrorides with polyauluinew. 
H. Noureddini, C.-Q. Zhang, and D. C. Timm, Reaction Kinetics Analyses of Amine-Cured Epoxies: First Shell Substitution Effects. (C) Macromolecules; 1994; 27(8); 2045-2053.

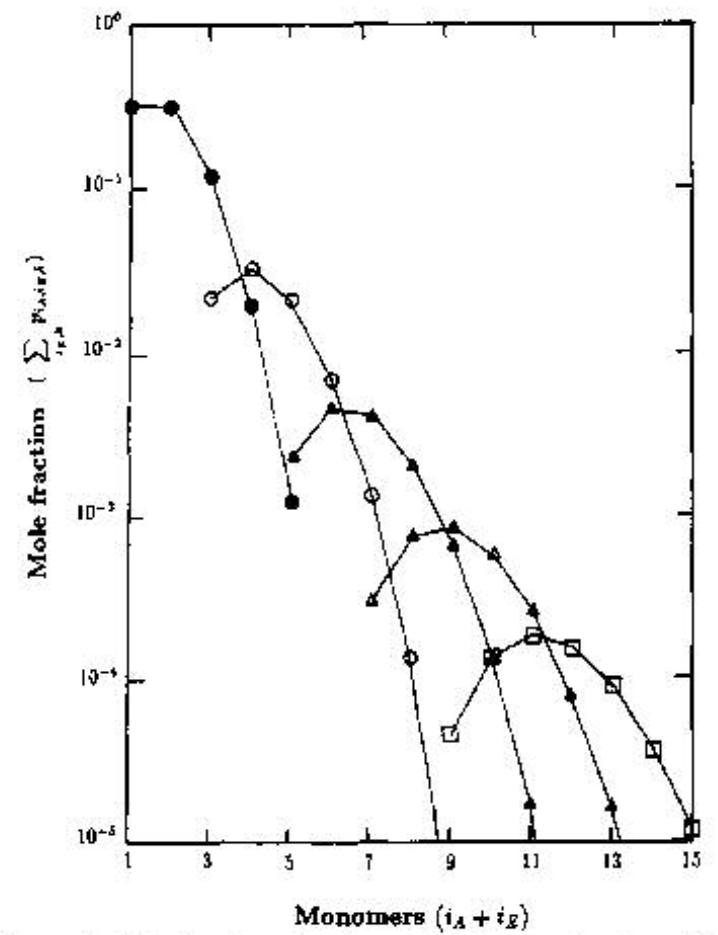

Figure 2. Mole fraction of various molecules as a function of the total number of epoxy and amine monomers at conversion equal to 0.250 , subject to $c_{1}=1.0,5=2.0, f_{A}=f_{K}=2$ and secopd-order

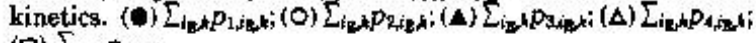
(a) $\sum_{i k, k} p_{0, j, k}$.

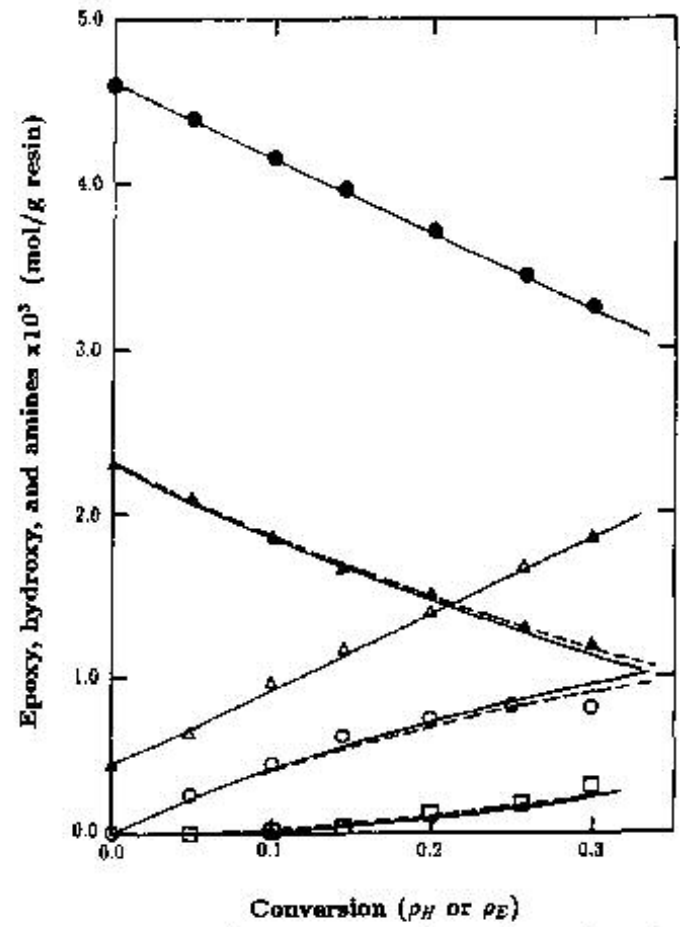

Figure 3. Numerical simulations and experimental resulte of functional groups as a function of conversion in the system DGEBA/DAB subjec to $\zeta=2.0$ and third-order kinetics. (o)

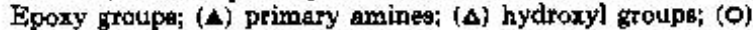
secondary amines; (D) tertiary amines; $(-) \mathrm{c}_{1}=1.00 ;(-\cdots) c_{t}=$ 1.20 . 
H. Noureddini, C.-Q. Zhang, and D. C. Timm, Reaction Kinetics Analyses of Amine-Cured Epoxies: First Shell Substitution Effects. (C) Macromolecules; 1994; 27(8); 2045-2053.

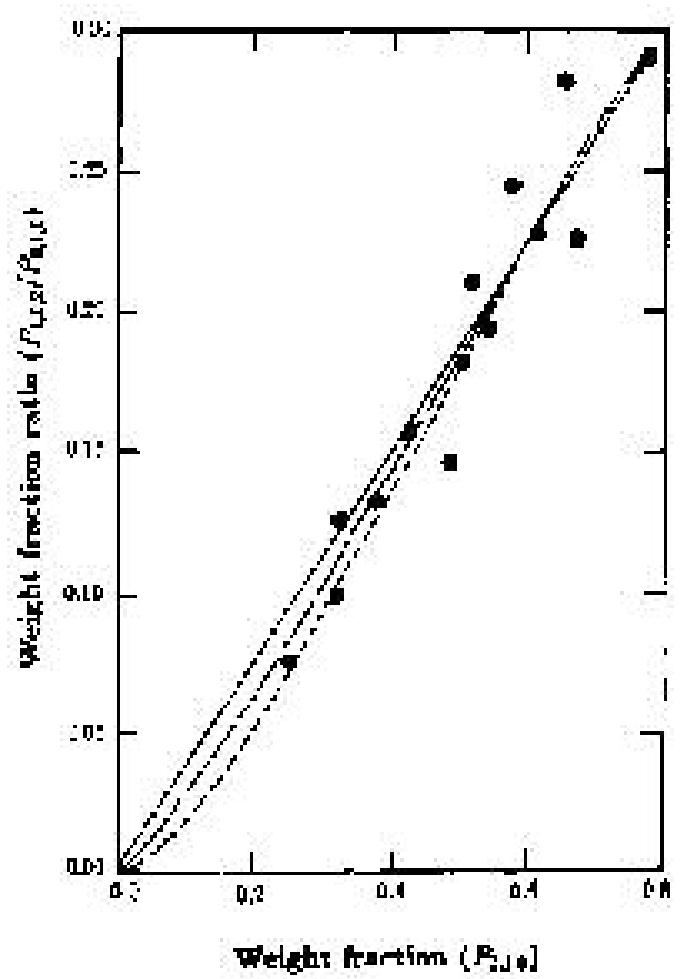

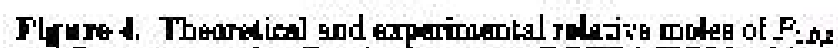

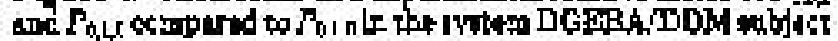

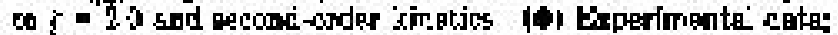

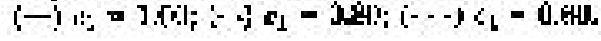

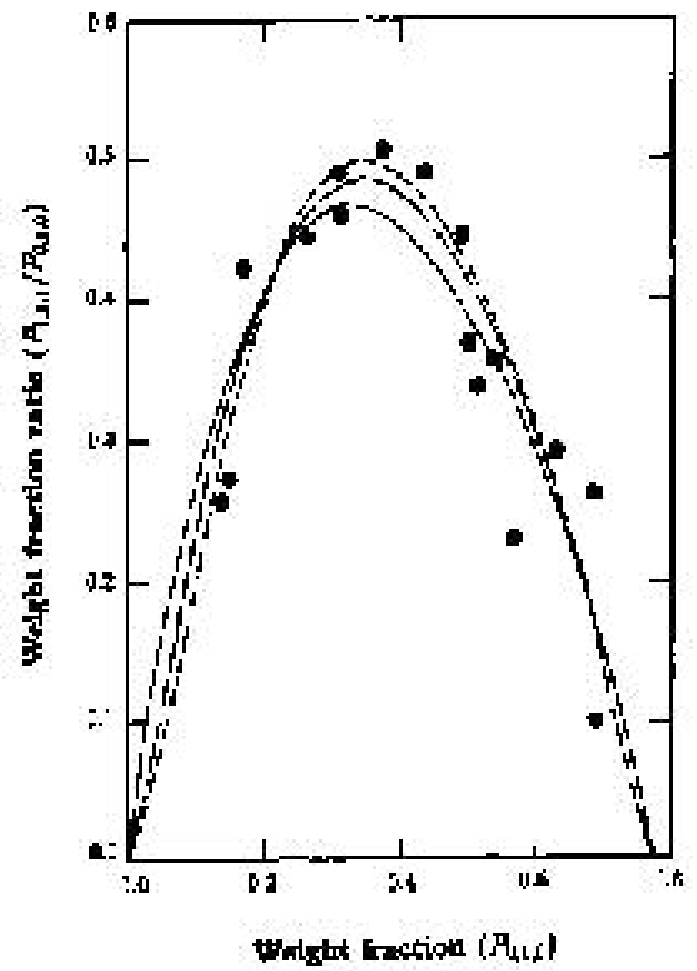

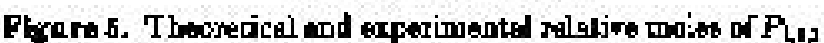

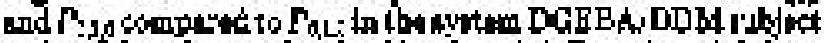

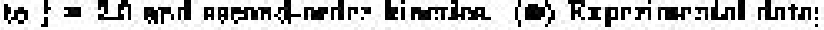

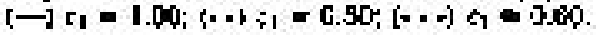


H. Noureddini, C.-Q. Zhang, and D. C. Timm, Reaction Kinetics Analyses of Amine-Cured Epoxies: First Shell Substitution Effects. (C) Macromolecules; 1994; 27(8); 2045-2053.

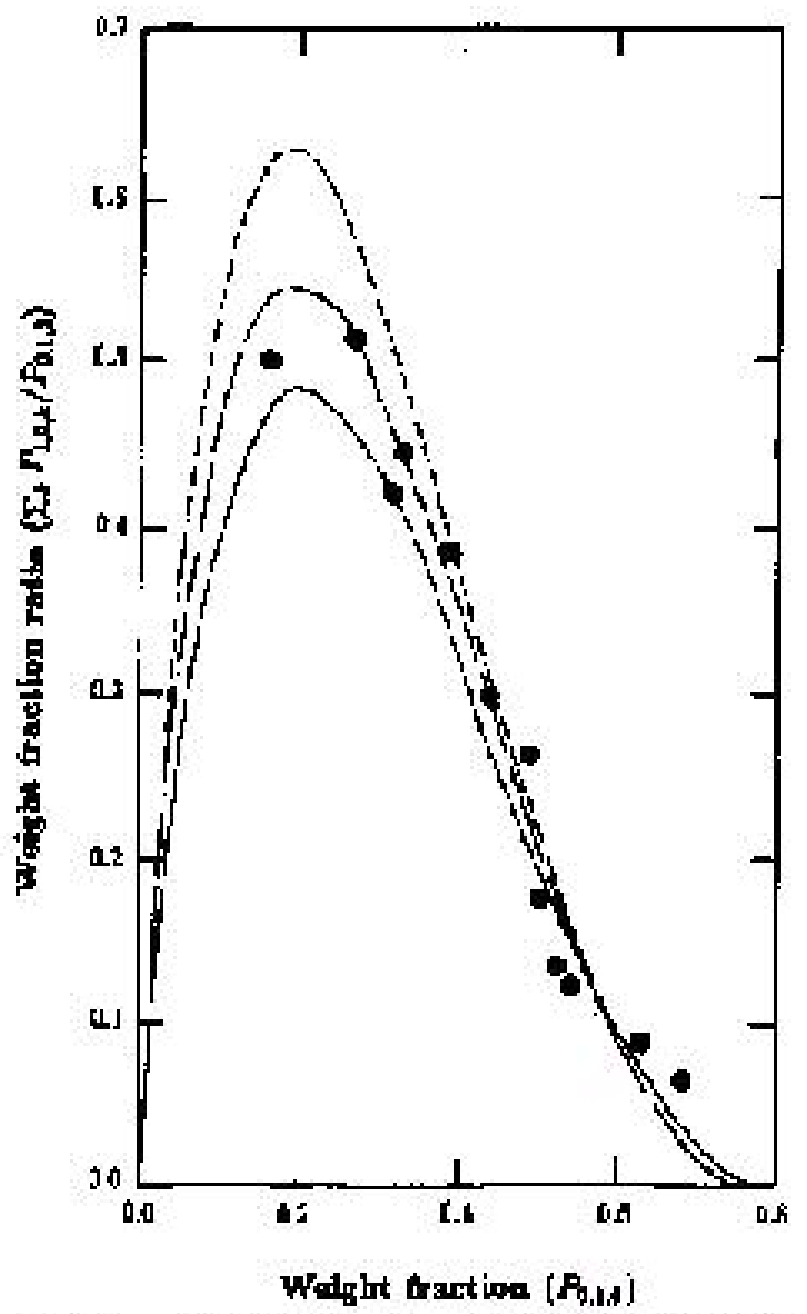

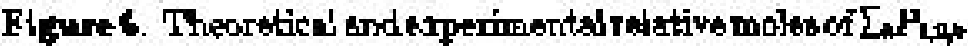
and $P_{0,10}$ cowpared $w P_{t, L 0}$ ir tha ays Leto DGEBADDM wubject. to t $=20$ and recrond-order kinotic (0) Enjerimental ifla;

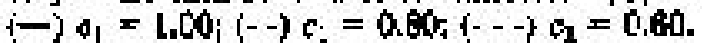


H. Noureddini, C.-Q. Zhang, and D. C. Timm, Reaction Kinetics Analyses of Amine-Cured Epoxies: First Shell Substitution Effects. (C) Macromolecules; 1994; 27(8); 2045-2053.

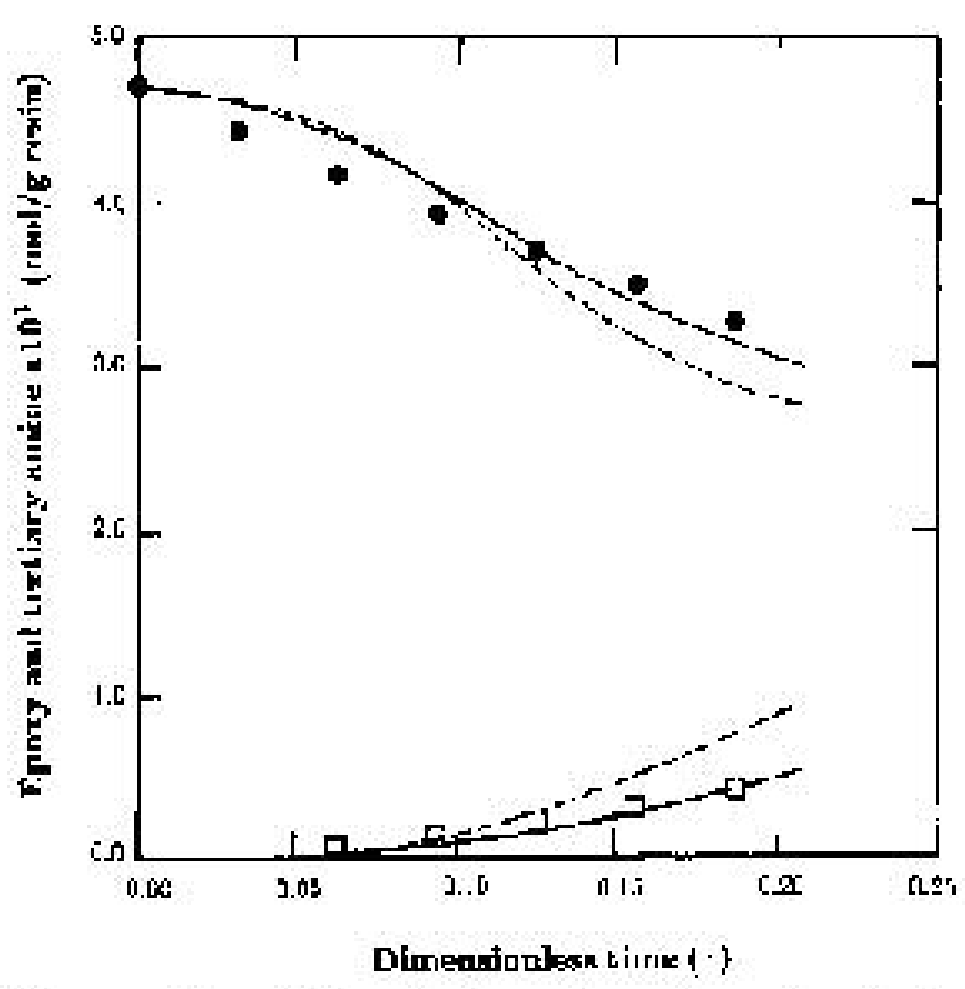

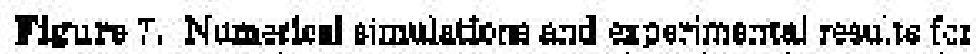
epozy aci.jpe and tertiary anings as a f-nction of time so the

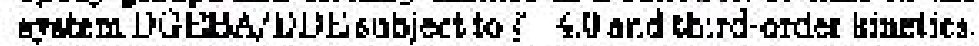

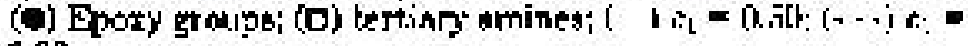
160. 